* Autor para correspondencia. Juan Badiano 1, Colonia Sección 16, C.P. 14080, Ciudad de México, México. Teléfono: (+52) (55) 5573 2911, Extensión: 1400, Fax: +52 5554851568 .

Correo electrónico: meddani@hotmail.com

(D. Hurtado-Sierra). http://dx.doi.org/10.1016/j.acmx.2016.04.009

1405-9940/

(c) 2016 Instituto Nacional de Cardiología Ignacio Chávez. Publicado por Masson Doyma México S.A. Este es un artículo Open Access bajo la CC BY-NC-ND licencia (http: / /creativecommons.org/ licencias/by-nc-nd/4.0/).

\section{Successful transradial antegrade recanalization of a chronic total occlusion of an anomalous circumflex artery arising from the right sinus of Valsalva}

\section{Revascularización anterógrada exitosa mediante acceso radial de una oclusión total crónica en una arteria circunfleja con origen anómalo en el seno derecho de Valsalva}

Dear Editor,

Primary congenital anomalies of the coronary arteries are rather rare with an incidence of $0.3-1.6 \% .^{1}$ Anomalous origin of the left circumflex (LCX) coronary artery from the right sinus of Valsalva is the most common congenital coronary variant, with prevalence at coronary angiography of $0.18-0.67 \% .^{2,3}$ Percutaneous coronary intervention ( $\left.\mathrm{PCl}\right)$ for an anomalous coronary artery is a technically challenging and complicated procedure. We report a very unusual case of an anomalous origin of a chronically occluded LCX artery arising directly from the right sinus of Valsalva that was successfully performed by transradial (TR) antegrade approach.

A 66-year-old female with a past medical history of hypertension presented with an 8-month history of exertional chest pain. An echocardiogram showed normal heart wall movement with normal left ventricular ejection fraction. She exercised for $8 \mathrm{~min}$ on the standard Bruce protocol and experienced chest pain, and was found to have a 2-mm ST-segment depression in the inferolateral leads at the end of exercise. After obtaining an informed consent, coronary angiography revealed absence of the left main coronary artery, accompanied with the left anterior descending coronary artery without significant obstructive atherosclerotic lesions (Fig. 1A) and an anomalous origin of a proximal chronically occluded LCX artery from right sinus of Valsalva with a retro-aortic course with the right coronary artery (RCA) and the LCX sharing a common ostium (Fig. 1B). It was a tapered chronic total occlusion (CTO) in the proximal portion of the anomalous LCX with bending $>45$ degrees detected within the CTO segment and $>20 \mathrm{~mm}$ occlusion length $($ JCTO score $=2) .{ }^{4}$ The CTO revascularization was performed from the right radial artery. Before the procedure, the patient was taking clopidogrel $(75 \mathrm{mg} /$ day) and aspirin $(100 \mathrm{mg} /$ day $)$ and during the procedure, received anticoagulation with unfractionated heparin $(70 \mathrm{UI} / \mathrm{kg})$ to achieve an activated clotting time of 250-300 s. With a
$6 \mathrm{Fr}$ Amplatz right (AR) 1 guiding catheter we made a double-wire antegrade technique, involving placement of a separate Sion ${ }^{\circledR}$ wire (Asahi Intecc, Japan) into the RCA to anchor the guide, followed by wiring of the anomalous LCX with a Pilot ${ }^{\circledR} 150$ wire (Abbott Vascular, Santa Clara, CA, USA) supported by a $1.0 \times 10 \mathrm{~mm}$ Falcon ${ }^{\circledR}$ CTO balloon (Invatec, Roncadelle, Italy). Next, we proceeded with the parallel wire technique with the use of a Pilot $^{\circledR}$ 200 wire. This wire punctured the proximal cap at a different position and was easily advanced to the distal true lumen (Fig. 1C). The occlusion was predilated with a $2.0 \times 20 \mathrm{~mm}$ Emerge $^{\circledR}$ semi-compliant balloon (Boston Scientific, Natick, MA,USA) restoring coronary blood flow. Finally, a $2.75 \times 38 \mathrm{~mm}$ Synergy ${ }^{\circledR}$ (Boston Scientific, Natick, MA, USA) bioabsorbable polymer drug-eluting stent was deployed (Fig. 1D) with a good angiographic result (Fig. 2A), which was confirmed by optical coherence tomography (Fig. 2B) and coronary computed tomography angiogram study after angioplasty (Fig. 2C).

To the best of our knowledge this is the first case presented of successful recanalization of a CTO in an anomalously arising LCX performed by TR antegrade approach. Anomalies of the origin and course of the LCX coronary artery are amongst the most frequently encountered. The anomalous LCX originates from the right coronary cusp, either directly, or as a branch from the RCA and courses behind the aorta to the left part of the atrioventricular sulcus, where it resumes its usual configuration. This anomaly is classified as benign since it is not known to predispose individuals to sudden cardiac death. However, some studies have proposed a higher incidence of atherosclerosis and myocardial infarction in the presence of this anomaly. ${ }^{5}$ Anomalies of the LCX artery pose several potential challenges to the interventional cardiologist. Selection of the appropriate equipment (guiding catheter/wire) assumes greater importance, ranging from successfully engaging the ostium of the anomalous coronary artery with adequate support to advance interventional devices and ultimately, concluding the procedure with minimal exposure to contrast agents and radiation. $\mathrm{PCl}$ on anomalous LCX vessels is technically feasible, with a high procedural success rate when performed by experienced operators. ${ }^{6}$ CTOs successful recanalization in patients with viable myocardium has been shown to reduce symptoms like angina decrease the need for surgery and improve survival. ${ }^{7}$ According to the standard practice of the majority of CTO-dedicated centers and operators, $\mathrm{PCI}$ on CTO are attempted using large guiding catheters and transfemoral approach. The TR approach is a valuable alternative to trans-femoral approach, which has been shown to reduce vascular complications and possibly be associated to a better clinical outcome. ${ }^{8}$ 

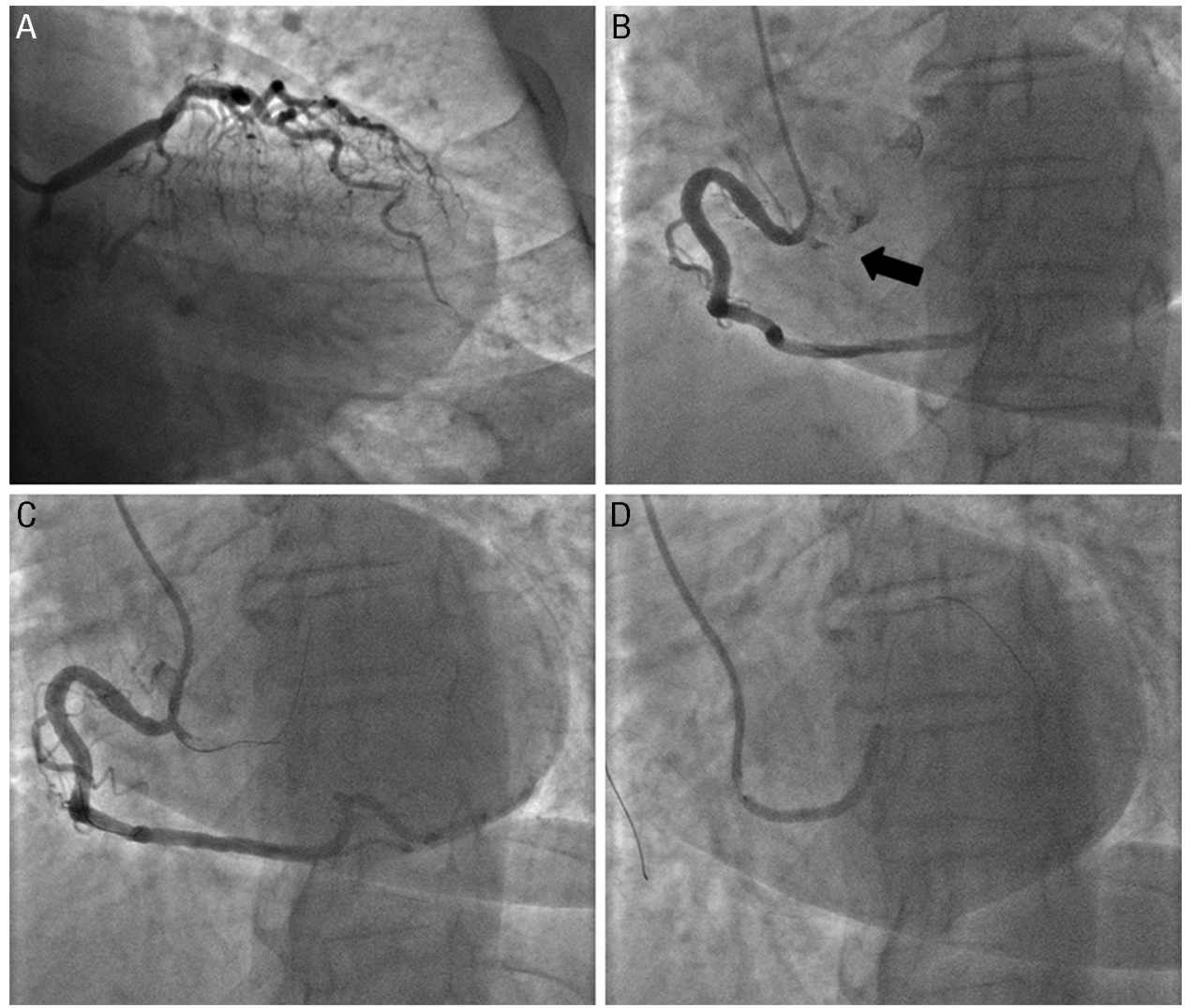

Figure 1 (A, B) Baseline coronary angiography. The arrow indicates the anomalous origin of a chronically occluded left circumflex artery. (C) Percutaneous coronary intervention with the chronic total occlusion successfully crossed. (D) Synergy ${ }^{\circledR}$ stent implanted.
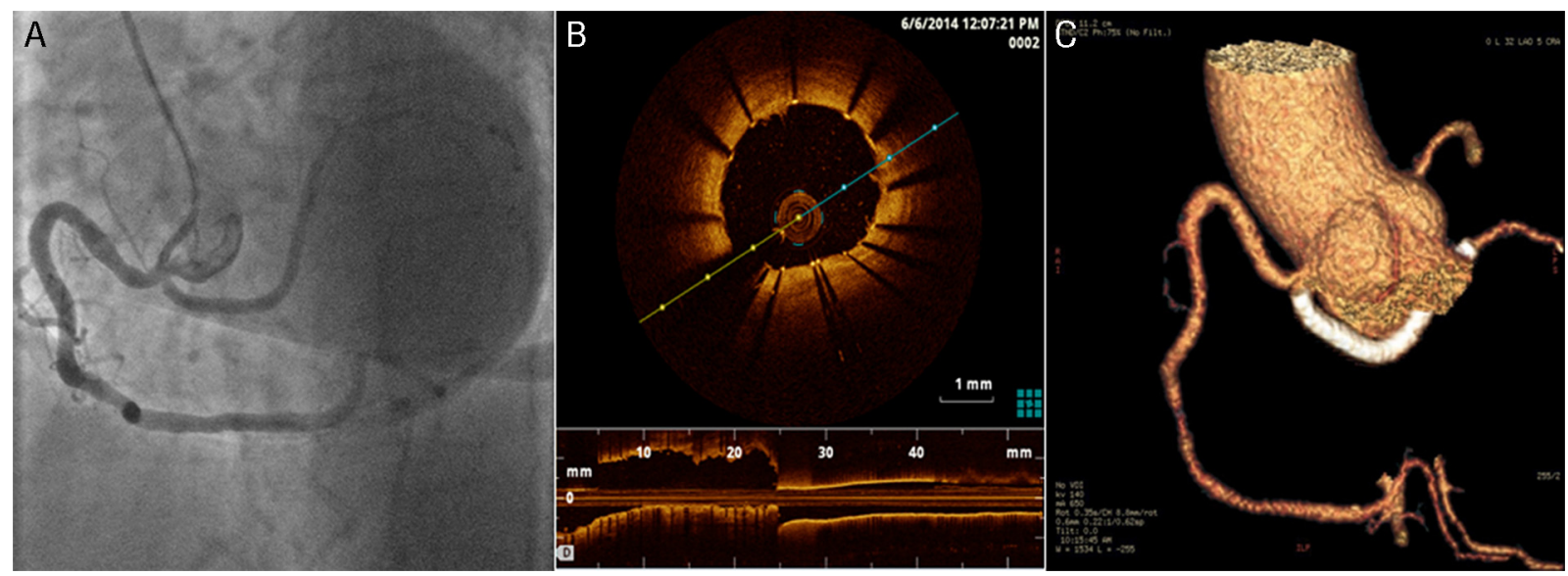

Figure 2 (A) Final angiographic result. (B) Optical coherence tomography image showing good stent apposition. (C) Coronary computed tomography angiogram after angioplasty. ficant. $\mathrm{PCl}$ for an anomalous coronary artery is a technically challenging and complicated procedure. We would like to emphasize the feasibility of a TR approach even for complex lesions such as the one in this patient.
Anomalous coronary arteries are rare and clinically signi-

\section{Conflict of interests}

The authors declare that there is no conflict of interests regarding the publication of this paper.

\section{Bibliografía}

\section{Funding}

None.
1. Angelini P, Velasco JA, Flamm S. Coronary anomalies: incidence, pathophysiology, and clinical relevance. Circulation. 2002;105:2449-54. 
2. Page HL, Engel HJ, Campbell WB, et al. Anomalous origin of the left circumflex coronary artery: recognition, angiographic demonstration and clinical significance. Circulation. 1974;50:768-73.

3. Wilkins CE, Betancourt B, Mathur VS, et al. Coronary artery anomalies: a review of more than 10,000 patients from the Clayton Cardiovascular Laboratories. Tex Heart Inst J. 1988;15:166-73.

4. Morino Y, Abe M, Morimoto T, et al. J CTO Registry Investigators. Predicting successful guidewire crossing through chronic total occlusion of native coronary lesions within 30 minutes: the J-CTO (Multicenter CTO Registry in Japan) score as a difficulty grading and time assessment tool. JACC Cardiovasc Interv. 2011;4:213-21.

5. Mohsen GA, Mohsin KG, Forsberg M, et al. Anomalous left circumflex artery from the right coronary cusp: a benign variant? Invasive Cardiol. 2013;25:284-7.

6. Morgan KP, Morris GM, Al-Najjar Y, et al. Percutaneous intervention on anomalous circumflex coronary arteries: a single centre experience. Cardiovasc Revasc Med. 2012;13: 335-40.

7. Suero JA, Marso SP, Jones PG, et al. Procedural outcomes and long-term survival among patients undergoing percutaneous coronary intervention of a chronic total occlusion in native coronary arteries: a 20-year experience. J Am Coll Cardiol. 2001;38:409-14.

8. Jolly SS, Amlani S, Hamon M, et al. Radial versus femoral access for coronary angiography or intervention and the impact on major bleeding and ischemic events: a systematic review and metaanalysis of randomized trials. Am Heart J. 2009;157:132-40.

Javier Benezet*, Antonio Agarrado,Jesús Oneto

Department of Cardiology, Hospital de Jerez de la Frontera, Jerez de la Frontera, Cádiz, Spain

* Corresponding author at: Servicio de Cardiología, Hospital de Jerez de la Frontera, Circunvalación s/n, 11407 Jerez de la Frontera, Cádiz, Spain.

E-mail address: javbenezet@hotmail.com (J. Benezet).

http://dx.doi.org/10.1016/j.acmx.2016.06.007 1405-9940/

(c) 2016 Instituto Nacional de Cardiología Ignacio Chávez. Published by Masson Doyma México S.A. This is an open access article under the CC BY-NC-ND license (http://creativecommons.org/licenses/ by-nc-nd/4.0/).

\section{Manejo de la mediastinitis postrasplante cardiaco mediante mediastinoscopia y perlas antibióticas de liberación prolongada}

\section{Dissolvable and extended release antibiotic beads in mediastinoscopic management of mediastinitis after heart transplantation}

Las complicaciones quirúrgicas relacionadas con la esternotomía media se pueden presentar en los pacientes postoperados de cirugía cardiaca como un amplio espectro de afecciones, que varían desde la dehiscencia de la herida quirúrgica hasta la mediastinitis supurativa. De este modo, los términos esternitis, mediastinitis, complicación de la herida e infección de la herida quirúrgica han sido utilizados indistintamente para denotar infección mediastinal profunda ${ }^{1}$.

En aquellos pacientes sometidos a trasplante cardiaco (TC), la mediastinitis posquirúrgica constituye una complicación grave y de difícil diagnóstico, que pone en riesgo la vida de los pacientes; además, muestra aspectos únicos debido al estado de inmunosupresión en el que estos se encuentran ${ }^{2}$.

Una vez establecido el diagnóstico, debe instituirse el tratamiento de inmediato, generalmente combinando antibioticoterapia con cirugía, lavado y desbridamiento intensivos. Por desgracia, el tratamiento convencional tiene varias desventajas, tales como la inestabilidad de la caja torácica, la inmovilización prolongada y el trauma quirúrgico sustancialmente mayor, que puede ser perjudicial ${ }^{3,4}$.

Al respecto, se ha descrito un gran número de abordajes quirúrgicos para el manejo de la mediastinitis; sin embargo, el tratamiento quirúrgico óptimo continúa siendo controversial. Basándose en los hallazgos tomográficos y los datos clínicos, resulta posible realizar incisiones y drenajes por vía transcervical, subxifoidea y toracoscópica y por toracotomía y mediastinoscopia videoasistida ${ }^{3}$.

El otro punto angular del tratamiento es la terapia con antibióticos. Uno de sus principales objetivos consiste en alcanzar altas concentraciones farmacológicas en el sitio de infección. Stimulan ${ }^{\circledR}$ (Biocomposites Ltd., Keele, Staffordshire, Reino Unido) es un medio absorbible para la liberación de antibióticos a nivel local y que ha probado su eficacia con anterioridad en la cirugía ortopédica, tanto en la profilaxis como en el tratamiento de la osteomielitis ${ }^{5}$.

A continuación presentamos nuestra experiencia con 2 casos de mediastinitis manejados mediante procedimiento de mínima invasión y colocación de perlas de liberación de antibióticos en pacientes sometidos a TC.

Se trató de 2 pacientes masculinos, ambos con antecedente de TC y bajo tratamiento inmunosupresor (a base de ácido micofenólico, prednisona y sirolimus), de 42 y 62 años de edad y con diagnóstico establecido de mediastinitis tipo IIIb y v de Oakley ${ }^{1}$, respectivamente.

Con base en los hallazgos tomográficos de ambos casos (fig. 1a b) se optó por realizar abordaje subxifoideo y mediastinoscopia (fig. 1c). Se realizó drenaje de las colecciones, lavado con abundante solución salina y desbridación del tejido infectado; además, se tomaron muestras de tejido y del exudado para cultivo. Se utilizó después del lavado instrumental limpio para la liberación in situ de antibióticos, con cambio de batas, campos y guantes para todo el equipo quirúrgico.

Posteriormente, se colocaron perlas de sulfato de calcio con antibiótico para liberación in situ (Stimulan ${ }^{\circledR}$ ); en el primer caso se utilizó imipenem/amikacina, y en el segundo paciente, imipenem/vancomicina y clindamicina (fig. 1d). Al final de la cirugía se dejó un sistema de drenaje cerrado a 